\title{
ReCALL
}

http://journals.cambridge.org/REC

Additional services for $\operatorname{ReCALL:}$

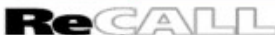

Email alerts: $\underline{\text { Click here }}$

Subscriptions: $\underline{\text { Click here }}$

Commercial reprints: $\underline{\text { Click here }}$

Terms of use : $\underline{\text { Click here }}$

\section{Affect and willingness to communicate in digital game- based learning}

Hayo Reinders and Sorada Wattana

ReCALL / Volume 27 / Issue 01 / January 2015, pp 38 - 57

DOI: 10.1017/S0958344014000226, Published online: 22 May 2014

Link to this article: http://journals.cambridge.org/abstract_S0958344014000226

How to cite this article:

Hayo Reinders and Sorada Wattana (2015). Affect and willingness to communicate in digital gamebased learning. ReCALL, 27, pp 38-57 doi:10.1017/S0958344014000226

Request Permissions : $\underline{\text { Click here }}$ 


\title{
Affect and willingness to communicate in digital game-based learning
}

\author{
HAYO REINDERS \\ Unitec, Auckland, New Zealand \\ (email: hayo@innovationinteaching.org) \\ SORADA WATTANA \\ Dhurakij Pundit University, Bangkok, Thailand \\ (email: sorada.wat@dpu.ac.th)
}

\begin{abstract}
The possible benefits of digital games for language learning and teaching have received increasing interest in recent years. Games are said, amongst others, to be motivating, to lower affective barriers in learning, and to encourage foreign or second language (L2) interaction. But how do learners actually experience the use of games? What impact does gameplay have on students' perceptions of themselves as learners, and how does this affect their learning practice? These questions are important as they are likely to influence the success of digital game-based language learning, and as a result the way teachers might integrate games into the curriculum. In this study we investigated the experiences of five students who had participated in a fifteen-week game-based learning program at a university in Thailand. We conducted six interviews with each of them (for a total of 30 interviews) to identify what impact gameplay had in particular on their willingness to communicate in English (MacIntyre, Dörnyei, Clément \& Noels, 1998). The results showed that gameplay had a number of benefits for the participants in this study, in particular in terms of lowering their affective barriers to learning and increasing their willingness to communicate. We discuss the implications of these results in terms of further research and classroom practice.
\end{abstract}

Keywords: digital games, digital game-based language learning (DGBLL), willingness to communicate (WTC)

\section{Digital game-based language learning}

The use of digital game-based language learning (DGBLL) has increased significantly in recent years and has received considerable attention in recent computer-assisted language learning (CALL) studies. In Gee's view, digital games are 'problem solving spaces that use continual learning and provide pathways to mastery through entertainment and pleasure' (Gee, 2009: 65). He argues that good digital games incorporate learning principles (Gee, 2007) and have a variety of design features that 'are particularly relevant to language learning' (Gee, 2012: xiii). 
Digital games have been investigated for their effects on language learning and recent studies have shown that different types of games can benefit successful vocabulary acquisition (deHaan, Reed \& Kuwada, 2010; Milton, Jonsen, Hirst \& Lindenburn, 2012; Ranalli, 2008); can help improve university students' reading skills and reading efficacy (H.-M. Lu, Lou, Papa \& Chung, 2011); and can help with the development of listening skills (deHaan, 2005a). In comparison to some other game genres, massively-multiplayer online role playing games (MMORPGs) have been investigated quite extensively in the CALL literature. Participation in MMORPGs has been shown to provide language learners with immersive (Gee, 2007; Zhao \& Lai, 2009) and linguistically rich and cognitively challenging environments (Sylvén \& Sundqvist, 2012), and sufficient opportunities, to acquire another language (Peterson, 2010b, 2012a, 2012b; Rankin, Gold \& Gooch, 2006). Specifically, MMORPGs afford learners opportunities to learn conversational language, use and practise the L2 (T. Bryant, 2006; Peterson, 2011; Thorne, 2008; Thorne, Black \& Sykes, 2009), engage in various forms of interaction (such as negotiation of meaning) necessary for language learning (Peterson, 2012b), foster pragmatic development (Thorne, 2008), and develop their communicative competence, especially when played together with native speakers and learners from different countries (Peterson, 2010a, 2010b; Rama, Black, van Es \& Warschauer, 2012). In addition to these benefits for L2 acquisition, other major purported benefits of gameplay are in the affective domain. We now consider previous studies that have investigated this aspect.

\section{Learners' experiences of digital game-based language learning}

In addition to the focus on learning gains (see preceding section), another focus of research has been on the subjective experience of playing games and its effect on learners' affective barriers or negative psychological variables, including low motivation, negative attitudes, high anxiety, and low self-confidence, which may interfere with the language acquisition process. According to Krashen (1981), learners with low affective filters (i.e., when they have high motivation, positive attitude, high self-confidence, and low anxiety) are likely to concentrate on language learning, use the L2, accomplish a task, receive comprehensible input, and acquire another language. Encouraging a low affective filter has been identified as one of the positive qualities of gaming (García-Carbonell, Rising, Montero \& Watts, 2001). Computer games appear to come with certain environments, characteristics and design features that provide a low stress atmosphere, helping learners feel relaxed, confident, and motivated to use the L2 (Anyaegbu, Ting \& Li, 2012; Gee, 2007; Hubbard, 1991; Li, Liu \& Boyer, 2009; Zhao \& Lai, 2009). This can facilitate lowering of the affective barriers and subsequently promote more opportunities for learners to become willing to communicate and thus use more L2. MMORPGs, in particular, have been shown to have a number of key design features and characteristics that may lower anxiety while increasing confidence and motivation (deHaan, 2005b; Li et al., 2009; Peterson, 2010a, 2011; Rama et al., 2012; Voulgari, 2011; Zhao \& Lai, 2009; Zheng, Young, Brewer \& Wagner, 2009).

Anyaegbu, Ting, and Li (2012) investigated the effect of playing the educational game 'Mingoville' on the motivation of young Chinese learners of English as a foreign language (EFL). The qualitative findings, investigated with 229 students through observation, field notes, interview and literature review, indicated that the majority of their students felt motivated to learn English with Mingoville because the game was fun for them and made 
them feel relaxed, offered them opportunities to become autonomous, avoid losing face, encouraged collaboration, gave them frequent rewards and encouragement, fostered their problem-solving skills, and created a good learning environment that allowed learners to increase their interest, broaden their exposure to English, participate actively, and receive multiple forms of language support. However, some students did not like games in general, and for them the experience had been demotivating. This supports Whitton's $(2007,2011)$ view that employing games for motivational purposes alone is not a sufficient justification because games may not be motivating for all students, particularly students in Higher Education. Therefore, digital games should only be used if they can provide additional benefits. Also, additional support is needed before games are employed (deHaan, 2005a).

Recent studies by Peterson (2012a, 2012b) focused specifically on learner interaction and attitudes in MMORPGs. In his qualitative study (Peterson, 2012a) of the use of the MMORPG 'NineRift,' six Japanese EFL university students participated in two gaming sessions, lasting approximately 90 minutes each, which were held one week apart. Peterson obtained data from learners' chat messages exchanged during gameplay, researcher observations, filed notes, learner responses to pre- and post-study questionnaires, and interviews. The findings indicated that learners actively participated in the game, utilized different types of strategy to manage their interaction, undertook collaborative dialogues exclusively in the L2, and had positive attitudes, claiming that interaction in MMORPGs was engaging, motivating, and enjoyable, and improved their fluency and discourse management practice. In a later study, Peterson (2012b) investigated the linguistic and social interaction and attitudes of four intermediate Japanese EFL university students in the MMORPG 'Wonderland'. Participants were engaged in four sessions, lasting approximately 70 minutes each and held once a week over a period of one month. Similar to the findings from the earlier study, participants used a range of strategies, and conducted their interaction exclusively in the target language. Moreover, participants provided largely positive feedback, claiming that interaction in MMORPGs, in combination with the anonymity provided by the use of pseudonyms and avatars, helped to reduce anxiety levels and encouraged opportunities for taking risks in using the target language, and, thus, creative and extensive use of the language. This feedback thus mirrored findings reported in the literature on learner interaction in MMORPGs (e.g., deHaan, 2005b; Peterson, 2011; Rankin, McNeal, Shute \& Gooch, 2008).

\section{Willingness to communicate}

The construct of willingness to communicate (WTC) is seen as a final step before actual L2 use (MacIntyre et al., 1998). An increase in WTC has been found to offer positive effects on L2 learning and acquisition; L2 learners with high levels of WTC are more likely to benefit from communicative language teaching (Ellis, 2004), interact in the L2 more frequently (Clément, Baker \& MacIntyre, 2003; MacIntyre \& Charos, 1996; Yashima, 2002), have more potential to practise in the L2 (MacIntyre, Baker, Clément \& Conrod, 2001; MacIntyre \& Gardner, 1991; Peng \& Woodrow, 2010), are more inclined to take risks using the L2 to communicate (Oxford, 1997), have more opportunities for authentic L2 use, become more active and autonomous learners (Kang, 2005), acquire higher levels of language fluency (Derwing, Munro \& Thomson, 2008), and generally achieve greater language proficiency (MacIntyre et al., 2001; MacIntyre et al., 1998; Yashima, 2002) and, as a result, show 
more improvement in communication skills (Yashima, Zenuk-Nishide \& Shimizu, 2004). Accordingly, engendering WTC in the L2 has been suggested by scholars such as MacIntyre et al. (1998) and Dörnyei (2001) as a crucial goal for L2 pedagogy. In particular, in the Southeast Asian context in which this study was conducted, WTC seems to be a good predictor of L2 interaction, more so than motivation alone. The relationship between WTC and motivation is a complicated one: space constraints do not allow us to offer a detailed discussion here. Instead, we refer the reader to MacIntyre et al. (2001) and Dörnyei (2009). In summary, however, WTC is related to but separate from constructs such as motivation and affect. For example, a more motivated learner may be more likely to be more willing to communicate, but this is not necessarily so. Affective barriers may impact on motivational levels, as well as WTC, but not necessarily in the same ways. In other words, the constructs interact, but the main distinguishing factor of WTC is its emphasis on a commitment to L2 production; encouraging L2 speaking in particular is a major concern to many teachers in Thailand, the setting for our study.

One measure of the success of a language programme is thus its ability to encourage WTC among its students. Consequently, research has pointed to instructional strategies, specific learning environments, and tasks conductive to the fostering of WTC. For example, studies by Cao (2006), Compton (2004a), and Y. Lu \& Hsu (2008) showed the importance of creating a supportive communication environment that lowers students' anxiety levels while increasing their self-perceived communicative competence to generate greater WTC and thus increased L2 interaction. Technology, and in particular CMC has been widely investigated as a source of creating this desired atmosphere. Compton (2004b), for example, revealed that chatting helped students to feel confident and, in consequence, willing to participate orally in class discussions. However, the impact of chat on WTC varied from learner to learner and was dependent on a number of factors, particularly the topics of discussion and the attitudes of their partners. Chat transcripts of these students indicated that some showed a high level of WTC as they made a lot of contributions in both number of words and turns. In addition, journal entries by some students, especially those with low levels of oral proficiency and low state communicative self-confidence, indicated that chatting helped them to feel more prepared and organize their ideas, thus leading to improved perception of their communicative competence and confidence before participating in a speaking task.

A study by Jarrell and Freiermuth (2005) also examined the use of Internet chat in the language classroom as a means of interaction and a medium to motivate learners and increase their WTC. The authors revealed that the majority of their students preferred chat to face-to-face interaction and that they were generally motivated to communicate in English using Internet chat. They also concluded that chat was a potentially motivating tool because it appeared 'to increase students' WTC' (op. cit.: 70). In a related study, Freiermuth and Jarrell (2006) further explored the use of chat as a means to complete tasks in small groups and investigated the effects the tool had on Japanese university students' WTC through a comparison with students solving the same tasks in face-to-face settings. Consistent with previous research in CMC (Kelm, 1992; Kern, 1995; Warschauer, 1996), the results of this study showed the benefits of chat on increasing students' intrinsic motivation and reducing their anxiety and inhibition to communicate in the target language. That is, data gathered from the post-test questionnaire and an analysis of the discourse produced by students showed that the majority of students who participated in this study produced a greater 
amount of language output, experienced more intrinsic motivation to communicate in English and less anxiety about communication, and, importantly, were more willing to communicate as a result of using chat in class.

CALL in the form of computer games appears to have potential for encouraging some aspects of the variables influencing WTC. This is evident in our pilot study (Reinders \& Wattana, 2011, 2012) which investigated the use of commercial MMORPG 'Ragnarok Online' in a real English classroom setting, and the effects gameplay had on learners' interaction and WTC in English. Sixteen university students were engaged in three computer game sessions of 4 hours and 30 minutes' duration. They were also asked to complete questionnaires eliciting their WTC level during gameplay. In addition to learners' significantly increased L2 interaction, their responses to questionnaires indicated that the level of WTC was likely to be enhanced by taking part in the game, as positive perceptions of WTC, low anxiety when interacting in English, high self-perceived communicative competence, and high frequency of English use, were reported. This suggested that language learners benefited from less stressful environments within the game and thus were willing to use the opportunities provided to use the L2. This paper reports on our subsequent study which looked more closely at the impact of gameplay on these aspects of learners' experiences.

\section{Summary of findings and gaps in the literature}

Although there is now an increasingly broad range of studies showing benefits of gameplay for L2 learning, most of these are exploratory, limited in scope and focusing mainly on anecdotal and descriptive evidence and examining the characteristics of games rather than their effects on the language learning process. Additionally, the literature mostly provides subjective views on the various affordances of games for language learning only. In addition, relatively little is known about their impact on the affective element of learning. For example, what is still unclear is if gameplay indeed leads to higher levels of WTC, lowers anxiety, and/or increases motivation. We aim to address this gap in our study, and also report on the implementation of gameplay in formal education in Thailand, a setting that has to this point rarely been reported on.

\section{Our study}

The main aim of this study was to investigate the effects of participating in an online game on EFL learners' WTC in English. Our research question was:

\section{How do Thai EFL learners experience playing digital games and how does this affect their WTC in English?}

WTC is defined as an individual's 'readiness to enter into discourse at a particular time with a specific person or persons, using a L2 [second language]' (MacIntyre et al., 1998: 547). Building on this, in our study we operationally defined WTC as 'an individual's intention to initiate or participate in communication in English at a particular moment in a particular situation.' Intention can be understood and determined through (a) perceptions of willingness to use English for communication, (b) feelings about communicating in English, in terms of self-confidence (i.e., a combination of low anxiety and sufficient levels of self-perceived communicative competence in English), and (c) frequency of communication in English. 
The study was conducted with 30 Thai EFL students enrolled in a 15-week university language course, English for Information Technology, which was designed and taught by one of the researchers. The focus of the course lay primarily in all-round skills development (i.e., reading, listening, speaking, writing, and grammar) and practical English communication skills practice. All participants were third-year students majoring in IT and had different English language proficiency levels (thirteen elementary students, eight lower intermediate students, seven upper intermediate students, and two advanced students). The course covered six units, taught over eighteen face-to-face classroom lessons. At the end of each unit, participants completed a review session by playing the popular game 'Ragnarok Online' and completing a quest (i.e., a mission that players are assigned to accomplish within a game). Gameplay took place during normal lesson time.

With permission from the game's local distributor, we were able to host the game on a private server in the CALL lab of the university, thereby giving us control over who could access the game, as well as to modify the game by creating six new quests in order to ensure its appropriateness to the L2 learning context and its alignment with the course's learning content and objectives.

After completion of each of the six computer game sessions, a semi-structured (Kvale, 1996), face-to-face interview was held with five randomly selected students (using a random number generator), allowing for rich descriptions of the effects of gameplay on WTC levels, in addition to the results from WTC questionnaires eliciting all 30 students' WTC when interacting in English in the class and the game (see Reinders \& Wattana, in press). The same five students were interviewed on each of the six occasions, for a total of 30 interviews, which would be sufficient to ascertain if saturation of data had taken place. There were three males and two females, aged between 19 and 22 years old, and they were not paid for participating in the interviews. They had in common that they had few opportunities to use English outside the classroom, which is typical of language learners in the Thai EFL setting, and which could affect their WTC.

The interviews involved eliciting narratives from the students by asking them to talk about their communicative experiences in every interview, and their perceptions of WTC in English while interacting in the game only in the final interview (see Appendix for the interview guide). The interviews thus gave some 'power and control' (Nunan, 2005: 150) to the participants by using mostly open questions to 'allow the respondents opportunities to develop their responses in ways which the interviewer might not have foreseen' (Campbell, McNamara \& Gilroy, 2004: 99). Students were provided with the chat transcripts of their last computer game session, allowing them to easily and accurately make comments on what they had done and how they had communicated in the game. The interviews were conducted in an informal manner, to help the students to feel comfortable and willing to share their experiences and thoughts. Also for this reason, the interviews were conducted in Thai and lasted between fifteen and 30 minutes, depending on the amount of detail each student was willing to provide. All interviews were digitally recorded and the interviews were transcribed verbatim within hours of each interview session. Selected excerpts for use in reporting the results and interpreting the findings were translated into English. Back translation was used to ascertain the accuracy of the translation.

The interview data were interpreted drawing on WTC theory. As mentioned above, this theory suggests that interaction in a non-threatening environment conducive to authentic language use, will lead to increased self-confidence, decreased anxiety, and increased 
willingness to practise and use the L2. The interview results were expected to identify whether gameplay had these effects. Beyond these general points of focus we did not employ rigorous pre-determined categories to allow for the possibility of discovering unanticipated realities (Adler \& Adler, 1998). Using grounded theory (Bryant \& Charmaz, 2007), the interview data were examined line by line by both researchers to search for key points and identify codes which were then grouped into concepts. Through constant comparison between concepts, core categories (communication anxiety, perceived communicative competence, and motivation) were identified as central themes to build a story. Representative comments were translated and a selection is reported below.

\section{Results}

During every interview session, students were asked to describe their experience (i.e., what they did and how they used English) while interacting in the game. During the last interview session students were in addition asked to talk about their WTC in English in the game (i.e., how they felt when using English, and did they think their WTC in English increased). Thus, learners' communicative experience and their WTC in English in the game are presented separately below.

\subsection{Learners' communicative experience in the game}

When asked what they did during gameplay and how they had used English, the students reported both favourable and unfavourable experiences during the six interview sessions. Four students were generally positive and their responses will be discussed first, followed by a discussion of the responses of the other student.

Alphabeat ${ }^{1}$ commented,

I enjoyed communicating in the game because I was able to use English exclusively, and because I had a chance to speak English more than just 'yes,' 'no,' or 'okay'.

(Interview session 1, 22 June 2010)

Similarly, Equal, who did not talk much in English in class but appeared to show increased participation in the game, felt that computer games contributed to her increase in L2 production and caused her to become a more active participant. She also explained how she experienced a positive emotional state and how she communicated during the first computer game session:

I used English a lot because I could communicate freely without the intervention of or the evaluation from the teacher, and I could say anything and do everything I could to accomplish a game task .... I did not have to, like, worry about the accuracy of grammatical forms, so I didn't feel pressured and, consequently [I was], very willing to try and interact in English.

(Equal, Interview session 1, 22 June 2010)

1 Individual students are referred to by their avatar (game characters) names (Alphabeat, Equal, BB, pUnpOp, and Follow-me) to provide anonymity. 
BB also reported that the low-anxiety atmosphere in the game allowed him freedom to interact in English. Interestingly, he said that he felt uninhibited to talk even though he did not know many things to say in the game. In addition, BB explained that the setting where gamers were represented by their avatars and player character names helped him to communicate freely in English, and he became relaxed when he did not have to face his partners directly. According to BB,

I didn't know who I was talking to in the game, so I didn't feel embarrassed, and, therefore, I could talk without worrying.

(Interview session 1, 22 June 2010)

Alphabeat echoed BB's opinion, reporting an inclination to talk more and freely in the game when he did not know who his partners were, and especially when his partners were funny, friendly, and supportive.

Being supportive of other game participants increased my confidence and encouraged my use of English.

(Interview session 2, 6 July 2010)

As time went by and as the students became more familiar with the game environment, they reported increased participation in English in the game and thought they were becoming more comfortable with and less anxious about using English during gameplay. BB explained that

the game created an atmosphere in which I wanted to speak, not because I had to do so.

(Interview session 3, 16 July 2010)

Both BB and pUnpOp also stated that

It was the computer game environment that made me more enthusiastic about using English.

(Interview session 5, 24 August 2010)

In addition, Alphabeat, $\mathrm{BB}$ and $\mathrm{pUnpOp}$, who appeared to be very active in most computer game sessions, reported their willingness to take risks in using English during interaction in the game. Risk-taking here was conceptualized as individuals' tendency to use the L2 regardless of uncertain outcomes (Peng, 2007). Generally, risk-taking was indicated by most of the students in this study in forms of (a) an attempt to use linguistic elements that were difficult or complex, and that they had recently encountered or never tried before, (b) a tolerance of incorrect use of the language during gameplay, and (c) a willingness to guess. Alphabeat, in particular, explained his risk-taking while playing games:

I started from producing single words and simple structures to language patterns I had rarely produced in class, particularly forming questions. I can say that I did not place too much emphasis on the quality of the conversations and I did not spend too much time trying to comprehend what [non-player characters] NPCs and other [player 
characters] PCs meant. In fact, I did not really know what they said but I simply guessed what they meant. ... I would like to try to produce longer and more difficult sentences in the next computer game sessions.

(Alphabeat, Interview session 2, 6 July 2010)

Although a greater L2 use was consistently reported during the interviews, the four students all admitted to communicating in the first language (L1) with their partners, especially when they wanted to explain complicated ideas. Nevertheless, these four students reported making an attempt to reduce the use of the L1, improving their self-confidence, and feeling ready to use mainly the L2 throughout the computer game sessions. For instance, BB mentioned his considerable decrease in Thai use as the computer game sessions proceeded and reported his happiness that he could keep the communication in English going. According to BB,

I did not mix English and Thai in my conversations like I used to do.

(Interview session 6, 3 September 2010)

However, not all learners enjoyed the interaction or were willing to use L2 in the game. Follow-me, in particular, was observed mixing her English utterances with Thai and not participating in English much in the gaming sessions. She articulated her habit of reliance on Thai use and her uneasiness with computer game activities. She reported little use of English during gameplay because she found it too hard to use appropriate words or structures to express her ideas in English thoroughly. According to Follow-me,

I didn't know how to say it in English.

(Interview session 1, 22 June 2010, Interview session 3, 16 July 2010, and Interview session 4, 10 August 2010)

Moreover, she explained that her delay in giving responses to others was caused by her reliance on Thai-to-English translation while producing the language and on English-to-Thai translation while reading or listening.

Due to her insufficient communicative competence, she commented,

Sometimes I spent a great amount of time thinking and planning... I had to delay and withdraw from the communication.

(Interview session 3, 16 July 2010)

In addition, she explained that her non-participation and reticence in most game sessions was caused by a lack of familiarity with gameplay, the difficulty of the game tasks, and the number of interlocutors. She also felt nervous about not getting her meaning across:

I felt nervous if I had to speak without preparation. ... I feared that my partner would get confused or laugh at me because of my poor English. [If I was laughed at] I would feel embarrassed. 
Not surprisingly, Follow-me appeared to exhibit low risk-taking tendencies as she did not use English much during gameplay, and reported that she did not like using English in the game. In her words,

I usually remained silent when I wasn't sure about what I needed to say.

(Interview session 3, 16 July 2010)

and

I feared that I would make mistakes.

(Interview session 4, 10 August 2010)

During the last interview session, she also related that what she experienced while playing games sometimes discouraged her and reduced her WTC. She commented

I appreciated the benefits the game offered but I felt I could participate in English more in face-to-face conversations in the classroom.

(Interview session 6, 3 September 2010)

However, she did not give reasons for her preference of classroom interaction and her actual participation in the classroom was inconsistent with her claims, because she did not participate in English during class time either.

\subsection{Learners' willingness to communicate in the game}

During the last interview session a number of additional questions were asked, in an attempt to gauge students' general perceptions of their WTC in English while engaged in gameplay. Generally, participants reported lower communication anxiety, increased perceived communicative competence, and increased motivation to communicate in English and they reported these as the main reasons why they felt more willing to use English in a game environment.

6.2.1. Communication anxiety level. pUnpOp and Alphabeat noted in the interviews,

When I felt relaxed, I could use and understand what I read and heard better.

(pUnpOp, Interview session 6, 3 September 2010)

and

I felt I could produce the language fluently and became more relaxed and confident as I used it.

(Alphabeat, Interview session 6, 3 September 2010)

BB acknowledged the comfort allowed by the game and related that this state encouraged him to participate in English:

When I felt relaxed and was able to participate, I would look forward to chances of using more English.

and 
the more relaxed I became, the more willing I was to talk in English.

(Interview session 6, 3 September 2010)

Moreover, Equal found herself less anxious about making mistakes and indicated that the games elicited her WTC because they helped ease her fear of evaluation. She also added that her anxiety about communication decreased because of the immediate interaction in the game which required fluency, not accuracy, in English.

However, Follow-me, in particular, reported feelings of worry about communicating in English. She also complained that she experienced some level of frustration because conversations between players in the game were unordered. She commented:

The conversations were sometimes confusing to me, especially during text-based chat with many people at the same time. The messages were mixed up and at several points were said repeatedly. I was already nervous about how to play the game and I had to feel anxious about communicating at the same time. I think my willingness to communicate was affected by the anxiety and frustration I had while playing games so I did not want to participate much.

(Follow-me, Interview session 6, 3 September 2010)

6.2.2. Perceived communicative competence. Notably, BB indicated that computer games bolstered his confidence to use English to interact with others and explained that he felt he could provide explanations, ask questions, and express his feelings in the game more confidently. He also added that

Ifelt that my English was good enough to help other game participants.

(Interview session 6, 3 September 2010)

In addition, Alphabeat perceived himself to be more confident with his ability to use English while engaged in the game because he was less worried about making mistakes. He also added that he could make himself understood and could understand his interlocutors better. According to Alphabeat,

When I was confident, I could express what I wanted to say in English and I could understand others.

(Interview session 6, 3 September 2010)

Similarly, pUnpOp reported that he felt his English communication improved and became more fluent, stating,

Overall, I thought I could communicate better... my English was not perfect but it was produced faster.

(Interview session 6, 3 September 2010)

In contrast, Follow-me reported her inability to participate and her concern about making mistakes. She also commented that she sometimes lost confidence in her communication 
competence while engaged in the game, particularly when her English was not understood by others, when she could not understand others, and when she did not know how to explain something in English. She therefore felt less willing to engage using English. According to Follow-me,

I felt incompetent because I could not explain many things in English and I inevitably used Thai.

and

I was not able to feel confident when I thought that the English I produced was incorrect or when I had to initiate a conversation.

(Interview session 6, 3 September 2010)

6.2.3. Motivation to communicate in English. All the five students reported an increase in motivation to participate in English in the game because they realised that gameplay was beneficial for their English improvement, especially their communication skills, in which they all wanted to develop the most. All students said that they were generally motivated and excited while engaged in the game and claimed that the fun and engaging environment in the game kept them motivated to try using English despite their imperfect use and understanding of the language. According to Alphabeat,

Since the game required collaboration and communication among players, I believed that what I said during the game was helpful to complete the tasks in the game and I wanted to share what I knew about the game with the other players as much as possible.

(Interview session 6, 3 September 2010)

Nevertheless, Follow-me, who demonstrated infrequent participation in the game, claimed that despite being motivated about talking in the game, she sometimes became bored with it, especially when she used the same words or talked about the same things several times and when she found a game task too difficult for her to participate.

Because of the positive influence of computer games on WTC, all the five students showed support for the use of this technology in English courses, as reported below.

\subsection{Future use of computer games in the English classrooms}

Four of the students generally indicated that computer game activities encouraged their motivation, use of authentic language, interaction between learners, and WTC and, eventually, helped them to improve their English. Even Follow-me, the only student who consistently claimed that she did not enjoy computer games much, did not oppose any future use of this kind of CALL activity. She argued that it was good to include computer games as part of the course because they offered new opportunities for language use; however, it was important to realise that not all learners felt comfortable with this technology, which then negatively affected their language learning process and performance. She also believed that computer game technology was not the only solution to promote language production and WTC. In her opinion, traditional face-to-face activities with which learners were familiar, or 
other computer applications could take them less amount of time to prepare and engage in but provide them with similar or better benefits.

\section{Discussion}

In summary, the participants' responses to the interview questions revealed a number of things about their experience:

Four of the students reported a greater amount of L2 production while engaged in the game during every interview session, showing their high WTC. When asked to elaborate on their responses, these four students claimed that they increasingly used English to interact with one another because they felt relaxed and confident about using the language (despite indicating occasional moments of frustration and some initial anxiety during the first computer game session), and because interaction in the game provided a safe context for them to use the language without worrying about making mistakes.

A key finding was that gameplay had lowered anxiety for all participants, even the one participant who did not enjoy gameplay as much as the others. One reason reported was that the participants felt the environment encouraged supportive interaction and the absence of an open, public sphere provided a degree of anonymity. Much has been written about the debilitating impact of anxiety on language learning and how commonly it is experienced by learners in regular classrooms (Arnold, 1999). The ability of DGBLL in our study to lower affective barriers is a major benefit to learning as it impacts on learners' self-efficacy and their identity (Gao \& Lamb, 2011). Another finding was that gameplay encouraged risktaking. The willingness to make mistakes and learn from them has been identified as one of the characteristics of successful language learners (Wanden, 1987) and as such this is a potentially important result of playing games, especially as these learners previously considered themselves as risk-averse in terms of communicating in the target language in the class. This is particularly pertinent in the Thai context where its typical language learners are anxious about L2 use (Bunrueng, 2008; Tasee, 2009) and afraid of making mistakes (Boonkit, 2010), and where the general learning culture does not encourage making mistakes (Holmes \& Tangtongtavy, 1997; Wiriyachitra, 2001), especially not in public. Related to this point was that participants made several comments about the game giving them a sense of 'freedom'. Thai classroom hierarchy is quite fixed and there is relatively little room for creativity, with a high degree of conformity and a focus on formal aspects of the language. The relaxed and open atmosphere in the game clearly also encouraged learners to engage in meaning-oriented interaction, rather than worry about grammatical errors. Their L2 production subsequently had the effect of making them feel proud of their performance.

Although evidence from one programme is not sufficient to make broad generalisations, it does appear that in this context gameplay initiated a virtuous cycle of lowered anxiety, resulting in a more $\mathrm{L} 2$ production, leading to greater self-satisfaction, and resulting in more motivation, which in turn led to a further lowering of affective barriers.

However, the findings were not positive for all. A challenge reported by one of the participants was the immediacy of the interaction. As Follow-me put it:

"The immediate interaction in the game wasn't good for me. I sometimes became very tense and couldn't express myself freely." 
From her other comments it was clear that she felt she needed more time to prepare her responses and the synchronous nature of the game did not suit her. This finding is similar to that reported by Anyaegbu, Ting and Li (2012) who also reported a small number of participants in their study who said they did not like gameplay. However, she did also feel that the game had been a motivating way to learn, despite her reservations. She felt games could have a role in language teaching, provided students such as herself, who were not comfortable with the medium, were taken into account, and that there would still be sufficient face-to-face instruction as well.

\subsection{Implications and suggestions for further research}

What do these results mean for language teachers? Firstly, we feel our findings indicate the potential of game-based learning to achieve a lowering of the affective barriers so many students experience in regular classrooms. Researchers have shown how a fear of speaking, losing face, and making mistakes in public (Liu \& Jackson, 2008), shyness (Chu, 2008), and lack of confidence and motivation (Peng \& Woodrow, 2010) result in less classroom participation. This applies in particular to Thai learners who are known to be reticent when it comes to communicating in English (Bennui, 2008; Bray, 2009; Kamprasertwong, 2010). DGBLL appears to be able to reduce these affective constraints on learning and may thus be a useful tool for teachers, perhaps especially in the early stages of a course, or with groups of learners who show particularly strong signs of facing affective challenges. Our results thus mirror those by Peterson (2012a) and Anyaebgu, Ting and Li (2012) who also found a positive effect on learners' attitudes towards target language communication and motivation.

Secondly, our results show that the participants felt they had communicated more in the target language. In many EFL situations the amount of target language production is particularly small (Kaplan \& Baldauf, 1997) and any increase in this is likely to have a positive impact on language acquisition (for a discussion of the relationship between target language production and language acquisition, see Swain \& Lapkin, 1995), pragmatic competence (Thorne, 2008) and negotiation of meaning, as shown in a previous study by Peterson (2010b). Teachers may find that the occasional use of game-based language learning can give learners increased opportunities to use the language.

Related to this, four of the five participants indicated that they felt more willing to communicate during gameplay. Clearly, not only do games give greater opportunity for target language interaction, learners may also feel more willing to seize these opportunities. It appears the collaborative environment of MMORPGs is particularly conducive to encouraging interaction, as previous studies have also confirmed (Zhao \& Lai, 2009; Zheng et al., 2009).

Finally, and in our view crucially, the use of games in class may give learners an alternative tool they can use to practise the target language out-of class, in their own time. Teachers who introduce their students to the possibility of using games for language learning may give them a tool for lifelong learning. However, it needs to be pointed out that our study involved a carefully (re)constructed environment in which learners only communicated with other learners in class and during which they were able to get support from the teacher at any time; our point is that simply referring students to games, or giving them time in class to play games, without adequate preparation and support may not be as successful. As with most pedagogical activities, much relies on the careful contribution of 
the teacher, especially also to enthuse learners who may be reluctant to use games, such as was the case for one of the participants in this study. As shown by her comments, the immediate nature of the game and the need to communicate without much preparation time, the focus on meaning rather than form, and the tolerance for mistakes, did not match her previous experiences nor her preference for learning by careful preparation and use of the target language in a structured environment. Previous studies have similarly shown that not all learners enjoy the experience of DGBLL (Anyaegbu, Ting \& Li 2012). Teachers can accommodate such students by offering a range of different tasks, for example by making time for learners to prepare for in-game communication.

\subsection{Limitations and further study}

We would like to acknowledge a number of limitations of our study. Firstly, one of the researchers of this study was also the main teacher of the course. Although she made concerted efforts to teach face-to-face and game supported classes in as similar a way as possible, her enthusiasm for the use of digital games may still have affected students' experience.

Secondly, only five out of a total of 30 participants were interviewed and this may have skewed the results. However, the findings from our pilot study (Reinders \& Wattana, 2011, 2012), which used an earlier version of the quests in Ragnarok Online used in this study, showed generally positive responses from participants on the questionnaires. Although these five participants were randomly selected, nevertheless, a greater number of participants would have been preferable. With a total of 30 interviews, however, we were unable to make time for more.

WTC in this study was investigated through participants' reports as given in the interviews. Another approach would be to observe actual language during gameplay and this is something we intend to do next. Future research could also carry out comparisons between what students report about their target language interaction and their actual language use.

Future research could further investigate the affective element of DGBLL on learning beyond the classroom. As Bleumers, Naessens and Jacobs (2010) argue, the impact of games takes place in a wider context and in order to understand this impact, the use of games needs to be situated and investigated in its full range of settings. Much remains to be discovered about the potential for DGBLL for learning and teaching.

\section{References}

Adler, P. A. and Adler, P. (1998) Peer power: Preadoloscent culture and identity. London: Rutgers University Press.

Anyaegbu, R., Ting, W. and Li, Y. (2012) Serious game motivation in an EFL classroom in Chinese primary school. TOJET: The Turkish Online Journal of Educational Technology, 11(1): 154-164. Arnold, J. (1999) Affect in language learning. Cambridge: Cambridge University Press.

Bennui, P. (2008) A study of L1 interference in the writing of Thai EFL students. Malaysian Journal of ELT Research, 4: 72-102.

Bleumers, L., Naessens, K. and Jacobs, A. (2010) How to approach a many splendored thing: Proxy Technology Assessment as a methodological praxis to study virtual experience. Journal of Virtual Worlds Research, 3(1): 1-24.

Boonkit, K. (2010) Enhancing the development of speaking skills for non-native speakers of English. Procedia - Social and Behavioral Sciences, 2(2): 1305-1309. 
Bray, L. (2009) Cultural dimensions for a foreigner teaching English in a Thai university. Pedagogies of Connection: TESOL in Context: Special Edition (May 2009), S2: 1-10.

Bryant, A. and Charmaz, K. (eds.) (2007) The SAGE Handbook of Grounded Theory. London: SAGE Publications Ltd.

Bryant, T. (2006) Using World of Warcraft and other MMORPGs to foster a targeted, social, and cooperative approach toward language learning. http://www.academiccommons.org/commons/ essay/bryant-MMORPGs-for-SLA\#comments.

Bunrueng, P. (2008) Anxiety in studying English for communication of Loei Rajabhat university students. Paper presented at the International Conference of Educational Research (ICER) on Learning Communities for Sustainable Development., KhonKaen, Thailand.

Campbell, A., McNamara, O. and Gilroy, P. (2004) Practitioner research and professional development in education. London: SAGE Publications Ltd.

Cao, Y. (2006) Temporal fluctuations in situational willingness to communicate in a second language classroom. New Zealand Studies in Applied Linguistics, 12(2): 1-16.

Chu, H.-N. R. (2008) Shyness and EFL learning in Taiwan: A study of shy and non-shy college students' use of strategies, foreign language anxiety, motivation, and willingness to communicate. Unpublished PhD dissertation, University of Texas at Austin.

Clément, R., Baker, S. C. and MacIntyre, P. D. (2003) Willingness to communicate in a second language: The effects of context, norms, and vitality. Journal of Language and Social Psychology, 22(2): 190-209.

Compton, L. (2004a) From chatting to oral fluency: Using chat to improve self-confidence and increase willingness to communicate. Teaching English with Technology, 4(1): 1-9.

Compton, L. (2004b) Using text chat to improve willingness to communicate. In: Son, J.-B. (ed.), ComputerAssisted Language Learning: Concepts, contexts, and practices. New York: iUniverse, Inc., 123-144.

deHaan, J. (2005a) Acquisition of Japanese as a foreign language through a baseball video game. Foreign Language Annuals, 38(2): 278-282.

deHaan, J. (2005b) Learning language through video games: A theoretical framework, an evaluation of game genres and questions for futher research. In: Schaffer, S. P. and Price, M. L. (eds.), Interactive convergence: Critical issues in multimedia. Oxford: Inter-Disciplinary Press, 229-239.

deHaan, J., Reed, W. M. and Kuwada, K. (2010) The effect of interactivity with a music video game on second language vocabulary recall. Language Learning \& Technology, 14(2): 74-94.

Derwing, T. M., Munro, M. J. and Thomson, R. I. (2008) A longitudinal study of ESL learners' fluency and comprehensibility development. Applied Linguistics, 29(3): 359-380.

Dörnyei, Z. (2001) New themes and approaches in second language motivation research. Annual Review of Applied Linguistics, 21: 43-59.

Dörnyei, Z. (2009) The Psychology of Second Language Acquisition. Oxford: Oxford University Press.

Ellis, R. (2004) Individual differences in second language learning. In: Davies, A. and Elder, C. (eds.), The Handbook of Applied Linguistics. Oxford: Blackwell Publishing, 525-551.

Freiermuth, M. and Jarrell, D. (2006) Willingesss to communicate: Can online chat help? International Journal of Applied Linguistics, 16(2): 189-212.

Gao, X. and Lamb, T. (2011) Exploring links between identity, motivation and autonomy. In: Murray, G., Gao, X. and Lamb, T. (eds.), Identity, motivation and autonomy in language learning. Bristol: Mutilingual Matters, 1-11.

García-Carbonell, A., Rising, B., Montero, B. and Watts, F. (2001) Simulation/Gaming and the acquisition of communicative competence in another language. Simulation \& Gaming, 32(4): 481-491.

Gee, J. P. (2007) What video games have to teach us about learning and literacy. Basingstoke: Palgrave Macmillan.

Gee, J. P. (2009) Deep learning properties of good digital games: How far can they go?. In: Ritterfeld, U., Cody, M. and Vorderer, P. (eds.), Serious games: Mechanisms and effects. New York: Routledge, 65-80. 
Gee, J. P. (2012) Foreword. In: Reinders, H. (ed.), Digital games in language learning and teaching. Basingstoke: Palgrave Macmillan.

Holmes, H. and Tangtongtavy, S. (1997) Working with the Thais: A guide to managing in Thailand. Bangkok: White Lotus.

Hubbard, P. (1991) Evaluating computer games for language learning. Simulation \& Gaming, 22(2): 220-223.

Jarrell, D. and Freiermuth, M. R. (2005) The motivational power of Internet chat. RELC Journal, 36(1): 59-72.

Kamprasertwong, M. (2010) Willingness to communicate in English speech as a second language: A study of Thai, Chinese, and Dutch Samples. Unpublished MA dissertation, University of Groningen, The Netherlands.

Kang, S.-J. (2005) Dynamic emergence of situational willingness to communicate in a second language. System, 33(2): 277-292.

Kaplan, R. B. and Baldauf, R. B. (1997) Language planning: From practice to theory. Clevedon, UK: Multilingual Matters.

Kelm, O. R. (1992) The use of synchronous computer networks in second language instruction: A preliminary report. Foreign Language Annals, 25: 441.

Kern, R. G. (1995) Restructuring classroom interaction with networked computers: Effects on quantity and characteristics of language production. The Modern Language Journal, 79(4): 457-476.

Krashen, S. (1981) Second Language Acquisition and Second Language Learning. Oxford: Pergamon Press.

Kvale, S. (1996) InterViews: An introduction to qualitative research interviewing. London: SAGE Publications Inc.

Li, Z., Liu, F. and Boyer, J. (2009) Amusing minds for joyful learning through e-games. In: Marriott, R. d. C. V. and Torres, P. L. (eds.), Handbook of research on e-learning methodologies for language acquisition. Hershey, NY: Information Science Reference, 132-150.

Liu, M. and Jackson, J. (2008) An exploration of Chinese EFL learners' unwillingness to communicate and foreign language anxiety. The Modern Language Journal, 92(1): 71-86.

Lu, H.-M., Lou, S.-J., Papa, C. and Chung, C.-C. (2011) Study on influence of adventure game on English reading confidence, motive and self-efficacy. In: Chang, M., Hwang, W.-Y., Chen, M.-P. and Müller, W. (eds.), Edutainment technologies. Educational games and virtual reality/augmented reality applications (Vol. 6872). Springer: Berlin, Heidelberg, 430-434.

$\mathrm{Lu}, \mathrm{Y}$. and Hsu, C.-F. (2008) Willingness to communicate in intercultural interactions between Chinese and Americans. Journal of Intercultural Communication Research, 37(2): 75-88.

MacIntyre, P. D., Baker, S. C., Clément, R. and Conrod, S. (2001) Willingness to communicate, social support, and language-learning orientations of immersion students. Studies in Second Language Acquisition, 23(3): 369-388.

MacIntyre, P. D. and Charos, C. (1996) Personality, attitudes, and affect as predictors of second language communication. Journal of Language and Social Psychology, 15(1): 3-26.

MacIntyre, P. D., Dörnyei, Z., Clément, R. and Noels, K. A. (1998) Conceptualizing willingness to communicate in a L2: A situational model of L2 confidence and affiliation. The Modern Language Journal, 82(4): 545-562.

MacIntyre, P. D. and Gardner, R. C. (1991) Investigating language class anxiety using the focused essay technique. The Modern Language Journal, 75(3): 296-304.

Milton, J., Jonsen, S., Hirst, S. and Lindenburn, S. (2012) Foreign language vocabulary development through activities in an online 3D environment. The Language Learning Journal, 40(1): 99-112.

Nunan, D. (2005) Research methods in language learning. Cambridge: Cambridge University Press.

Oxford, R. L. (1997) Cooperative learning, collaborative learning, and interaction: Three communicative strands in the language classroom. The Modern Language Journal, 81(4): 443-456. 
Peng, J.-E. (2007) Willingness to communicate in the Chinese EFL classroom: A cultural perspective. In: Liu, J. (ed.), English language teaching in China: New approaches, perspectives and standards. Bodmin, Cornwall, UK: Continuum, 250-269.

Peng, J.-E. and Woodrow, L. (2010) Willingness to communicate in English: A model in the Chinese EFL classroom context.. Language Learning, 60(4): 834-876.

Peterson, M. (2010a) Computerized games and simulations in computer-assisted language learning: A meta-analysis of research. Simulation \& Gaming, 41(1): 72-93.

Peterson, M. (2010b) Massively multiplayer online role-playing games as arenas for second language learning. Computer Assisted Language Learning, 23(5): 429-439.

Peterson, M. (2011) Digital gaming and second language development: Japanese learners interactions in a MMORPG. Digital Culture \& Education, 3(1): 56-73.

Peterson, M. (2012a) Language learner interaction in a massively multiplayer online role-playing games. In: Reinders, H. (ed.), Digital games in language learning and teaching. Basingstoke: Palgrave Macmillan, 70-92.

Peterson, M. (2012b) Learner interaction in a massively multiplayer online role playing game (MMORPG): A sociocultural discourse analysis. ReCALL, 24(3): 361-380.

Rama, P. S., Black, R. W., van Es, E. and Warschauer, M. (2012) Affordances for second language learning in World of Warcraft. ReCALL, 24(3): 322-338.

Ranalli, J. (2008) Learning English with The Sims: Exploring authentic computer simulation games for L2 learning. Computer Assisted Language Learning, 21(3): 441-445.

Rankin, Y., Gold, R. and Gooch, B. (2006) 3D role-playing game as language learning tools. Paper presented at the EuroGraphics 2006, Vienna, Austria.

Rankin, Y., McNeal, M., Shute, M. and Gooch, B. (2008) User centered game design: evaluating massive multiplayer online role playing games for second language acquisition. Paper presented at the 2008 ACM SIGGRAPH symposium on Video games, Los Angeles, California: ACM.

Reinders, H. and Wattana, S. (2011) Learn English or die: The effects of digital games on interaction and willingness to communicate in a foreign language. Digital Culture and Education, 3(1): 4-28.

Reinders, H. and Wattana, S. (2012) Talk to me! Games and students' willingness to communicate. In: Reinders, H. (ed.), Digital games in language learning and teaching. Basingstoke: Palgrave Macmillan, 156-188.

Reinders, H. and Wattana, S. (forthcoming) Can I say something? The effects of digital game play on willingness to communicate. Language Learning \& Technology.

Swain, M. and Lapkin, S. (1995) Problems in output and the cognitive processes they generate: A step towards second language learning. Applied Linguistics, 16: 371-391.

Sylvén, L. K. and Sundqvist, P. (2012) Gaming as extramural English L2 learning and L2 proficiency among young learners. ReCALL, 24(3): 302-321.

Tasee, P. (2009) Factors affecting English major students anxiety about speaking English. Unpublished doctoral dissertation, Suranaree University of Technology, Nakhon Ratchasima.

Thorne, S. L. (2008) Transcultural communication in open Internet environments and massively multiplayer online games. In: Magnan, S. S. (ed.), Mediating discourse online. Amsterdam: John Benjamins Publishing Company, 305-327.

Thorne, S. L., Black, R. W. and Sykes, J. M. (2009) Second language use, socialization, and learning in Internet interest communities and online gaming. The Modern Language Journal, 93(Focus Issue): 802-821.

Voulgari, I. (2011) Collaborative learning in massively multiplayer online games: A review of social, cognitive, and motivational perspectives. In: Felicia, P. (ed.), Handbook of research on improving learning and motivation through educational games: Multidisciplinary approaches (Vol. 1). Hershey: IGI Global, 370-394. 
Wanden, A. (1987) How to be a successful language learner: Insights and prescriptions from L2 learners. In: Wenden, A. and Rubin, J. (eds.), Learner strategies in language learning. Englewood Cliffs, NJ: Prentice Hall International, 159-168.

Warschauer, M. (1996) Comparing face-to-face and electronic discussion in the second language classroom. CALICO Journal, 13(2\&3): 7-26.

Whitton, N. (2007) Motivation and computer game based learning. ICT: Providing choices for learners and learning. Proceedings ascilite Singapore. 1063-1067.

Whitton, N. (2011) Theories of motivation for adults learning with games. In: Felicia, P. (ed.), Handbook of research on improving learning and motivation through educational games: Multidisciplinary approaches (Vol. 1). Hershey: IGI Global, 352-369.

Wiriyachitra, A. (2001) English language teaching and learning in Thailand in this decade. The Language Teacher Online, 25(6): 1-5.

Yashima, T. (2002) Willingness to communicate in a second language: The Japanese EFL context. The Modern Language Journal, 86(1): 54-66.

Yashima, T., Zenuk-Nishide, L. and Shimizu, K. (2004) The influence of attitudes and affect on willingness to communicate and second language communication. Language Learning, 54(1): 119-152.

Zhao, Y. and Lai, C. (2009) MMORPGs and foreign language education. In: Ferdig, R. E. (ed.), Handbook of research on effective electronic gaming in education (Vol. 1). New York: Information Science Reference, 402-421.

Zheng, D., Young, M. F., Brewer, R. A. and Wagner, M. (2009) Attitude and self-efficacy change: English language learning in virtual worlds. CALICO Journal, 27(1): 205-231.

\section{Appendix: Interview Guide}

\section{Opening}

Explain the reason for and the purpose of the interview, summarize briefly what will happen to the interview results, and reassure the interviewees on the issue of confidentiality.

\section{Interviewing}

Ask students to describe their general experience while interacting in the game.

- Tell me what you did during gameplay.

- Tell me how you used English during gameplay.

List of follow-up and probing questions:

- How/Why did you ? Can you explain this to me?

- What do you think caused

- I found you while playing games. Tell me why you did this. / Tell me why you responded here. /Tell me why you didn't say anything here.

\section{Ask students to talk about their willingness to communicate in English in the game. ${ }^{2}$}

- Tell me how you felt when communicating in English in the game and how your feelings affected your communication.

- Do you think your willingness to communicate in English increased during gameplay? Why? /Why not?

2 These three additional questions were asked during the last interview session only. 
List of follow-up and probing questions:

- Did you feel confident/nervous/comfortable? When?/Why?

- Can you remember any other feelings?

- You mentioned previously that you think Can you explain this to me?

\section{Closing / Ending the interview}

Thank participant for their contribution and ask if there is anything (s)he would like to add or ask. 